\title{
Upaya Preventif Stunting Dengan Pemantauan Tumbuh Kembang Dan Pendidikan Kesehatan Pada Ibu Balita di Desa Mojoranu Sooko Kabupaten Mojokerto
}

\author{
Sulis Diana, Nurun Ayati Khasanan*, Ferilia Adiesti, Fitria Edni Wari, Elyana \\ Mafticha \\ Program Studi D III Kebidanan, Sekolah Tinggi Ilmu Kesehatan Majapahit, Indonesia \\ *nurun.ayati@gmail.com
}

\begin{abstract}
ABSTRAK
Dalam Pelaksanaan pengabdian masyarakat ini pemberian pengetahuan memberikan kontribusi dalam pencegahan stunting yang mana salah satunya dipengaruhi oleh pengetahuan ibu. Dalam program pengabdian masyarakat ini dilakukan koordinasi dengan bidan desa, kader dan juga masyarakat. Dalam hal ini pengabdian masyarakat dilakukan dalam rangka pemenuhan Tri Darma Perguruan Tinggi dan Pendampingan kader terhadap pemantauan pertumbuhan dan perkembangan yang dibutuhkan dalam mencegah terjadinya keterlambatan pertumbuhan dan perkembangan oleh tenaga medis dan pendidikan kesehatan. Tujuan pengabdian ini adalah untuk meningkatkan pengetahuan ibu balita tentang stunting. Metode yang diberikan dengan model pemberian penyuluhan tatap muka kesehatan menggunakan media LCD dan pemantauan pertumbuhan dan perkembangan dengan KPSP.

Hasil pengabdian pada masyarakat ini adalah banyaknya pengetahuan yang diterima menjadi lebih baik. Peningkatan pengetahuan ini karena kader kesehatan dan ibu balita didampingi secara oleh mahasiswa bidan dan juga dosen kebidanan dalam memberikan pendidikan kesehatan, kader kesehatan dan ibu balita lebih fokus pada saat edukasi dan dapat menemukan solusi masalah stunting.
\end{abstract}

Kata Kunci: Preventif, Stunting, Tumbuh Kembang, Pendidikan Kesehatan

Received: June 8, 2020

Revised: June 28, 2020

Accepted: July 20, 2020

This is an open-acces article distributed under the terms of the Creative Commons Attribution-ShareAlike 4.0 International License

\section{PENDAHULUAN}

Pertumbuhan terhambat, atau stunting adalah status gizi berdasarkan tinggi badan per usia berada pada ambang batas ( $Z$ score) <-2 SD sampai dengan -3 SD (pendek/stunted) dan <-3SD (sangat pendek/severely stunted). Stunting meningkatkan risiko penyakit anak dan kematian, keterlambatan perkembangan motorik, fungsi kognitif dan prestasi sekolah yang lebih rendah, serta penurunan produktivitas kerja (World Health Organization, 2017).

Prevalensi Balita Stunting di Indonesia masih tingggi yaitu 29,6\% di atas batasan yang ditetapkan WHO (20\%) yang di tunjukkan pada Pemantauan Gizi 2017. Tahun 2015 


\section{Journal of Community Engagement in Health}

Indonesia menduduki posisi tertinggi ke-2 dibawah Laos untuk jumlah anak stunting. Indonesia merupakan negara nomor empat dengan angka stunting tertinggi di dunia.Kurang lebih sebanyak 9 juta atau 37 persen balita Indonesia mengalami stunting. Survei terbaru Badan Pusat Statistik (BPS) menunjukkan masalah gizi dan tumbuh kembang anak masih menjadi hambatan besar bagi pemerintah Indonesia untuk mendongkrak kualitas sumber daya manusia. Secara statistik pada September 2019, angka kemiskinan Indonesia menjadi 9,22 persen, turun 0,19 persen dibanding Maret 2019. Namun pada akhir Desember lalu BPS merilis prevalensi bayi di bawah lima tahun yang menderita stunting (bertubuh pendek) mencapai 27,7 persen pada 2019. Artinya 28 dari 100 balita masih memiliki tinggi badan kurang dari ukuran normal.Walau angka tersebut turun sekitar tiga persen dibanding tahun sebelumnya, tapi jumlah tersebut tetap tinggi karena WHO menetapkan batas atasnya 20\%. Dalam Rancangan Pembangunan Jangka Menengah Nasional (RPJMN) 2020-2024, pemerintah menargetkan angka stunting turun lebih drastis menjadi 19 persen pada 2024 (Anisa \& Fauziah, 2020).

Angka kejadian stunting yang tinggi di Indonesia disebabkan oleh beberapa faktor yang kompleks, seperti nutrisi, kebersihan dan praktik pengasuhan anak yang ditandai dengan keragaman pola makan yang buruk dan praktik pemberian makan yang kurang optimal, pendidikan ibu dan ayah yang rendah, gizi ibu yang tidak memadai, tinggi ibu yang lebih pendek, rendahnya pendapatan keluarga, berat badan lahir rendah, jarak kelahiran yang dekat, rendahnya pemberian ASI eksklusif, sanitasi dan praktik kebersihan yang tidak mencukupi, dan kerawanan pangan rumah tangga (Hall et al., 2018).

Meningkatkan perilaku dan pendidikan ibu adalah kunci untuk mengatasi stunting. Peningkatan pendidikan ibu, khususnya, secara konsisten dikaitkan dengan pengurangan stunting (Behrman et al., 2013). Hubungan yang kompleks antara pendidikan dan stunting ini kemungkinan dimediasi oleh faktor-faktor lain yang lebih proksimal. Sebagai contoh, Semba et al. mencatat bahwa ibu-ibu di Indonesia umumnya adalah pengasuh utama anakanak dan pendidikan ibu terkait dengan perilaku perlindungan termasuk peningkatan kunjungan ke pos kesehatan setempat atau posyandu, akses dan penggunaan jamban tertutup, imunisasi anak, dan penerimaan kapsul vitamin A. Perilaku pengasuhan pelindung orang tua ini mencerminkan pengetahuan ibu tentang, dan kemampuan untuk menerapkan, praktik yang mendukung pertumbuhan dan perkembangan anak (Hall et al., 2018).

Upaya untuk meningkatkan pengetahuan terkait stunting pada ibu merupakan pendekatan yang efektif untuk mengatasi dan mencegah stunting. Contoh pengetahuan dapat mencakup lebih meningkatkan kesadaran praktik pemberian makan yang sehat, pengetahuan tentang keragaman nutrisi di antara berbagai pilihan makanan yang tersedia, mampu mengidentifikasi dengan benar stunting dan status gizi secara lebih luas, dan praktik pengasuhan anak (West et al., 2018).

\section{BAHAN DAN METODE}

Pengabdian masyarakat ini dilaksanakan didesa Mojoranu Kecamatan Sooko Kabupaten Mojokerto. Program ini ditujukan kepada semua balita dan ibu balita. Sebelum pelaksanaan program dilaksanakan, hal pertama yang dilakukan yaitu koordinasi dengan bidan desa, kader, dan masyarakat terkait peserta, waktu, tempat dan acara yang dilaksanakan. Selanjutnya tim melakukan sosialisasi terkait rencana serangkaian pelaksanaan program yang disampakan kepada bidan desa.Yang mana dilakukan oleh dosen dan dibantu mahasiswa D3 Kebidanan Mojokerto. 


\section{Journal of Community Engagement in Health}

http://jceh.org

Pengabdian masyarakat ini dilaksanakan dengan melakukan pengukuran berat badan dan tinggi badan, pengukuran perkembangan dengan menggunakan KPSP pada semua balita, pemberian pendidikan kesehatan pada ibu balita tentang stunting, cara pemilihan dan pemberian makanan sehat. Pemberian pendidikan kesehatan ini dilaksanakan dengan cara model penyuluhan tatap muka dan dengan pemeberian leaflet kepada semua ibu balita dan dilaksanakan demonstrasi tentang pengelolaan makanan sehat untuk balita di setiap posyandu. Evaluasi pelaksanaan program dilaksanakan pengukuran pengetahuan ibu balita tentang stunting dan pemberian makanan sehat.

\section{HASIL}

Kegiatan pengabdian masyarakat ini berjalan dengan baik, semua peserta memberikan respon positif dalam hal kemanfaatan yang tinggi pada ibu balita dengan harapan agar balita dapat tumbuh sehat sesuai pertumbuhan dan perkembangannya sehingga angka kejadian stunting menurun. Hasil pelaksanaan program kami sajikan dalam tabel dibawah ini :

Tabel 1. Data Umum Balita

\begin{tabular}{ccc}
\hline Data Umum & Frekuensi (n) & Persentase (\%) \\
\hline Jenis Kelamin & & \\
\hline Laki-laki & 63 & 57,8 \\
\hline Perempuan & 46 & 42,2 \\
\hline Jumlah & 109 & 100 \\
\hline Usia Balita & & 35,8 \\
\hline 12-35 Bulan & 39 & 64,2 \\
\hline $36-60$ Bulan & 70 & 100 \\
\hline Jumlah & 109 &
\end{tabular}

Tabel 2. Pemantauan Pertumbuhan dan Perkembangan Balita

\begin{tabular}{ccc}
\hline $\begin{array}{c}\text { Pertumbuhan dan } \\
\text { Perkembangan }\end{array}$ & Frekuensi (n) & Persentase (\%) \\
\hline Status Gizi & 10 & 9,2 \\
\hline Kurang & 95 & 87,2 \\
\hline Baik & 4 & 3,7 \\
\hline Lebih & 109 & 100 \\
\hline Jumlah & & 89 \\
\hline Perkembangan & 97 & 11 \\
\hline Normal & 12 & 100 \\
\hline Meragukan & 109 &
\end{tabular}

Tabel 3. Pengetahuan Ibu Balita

\begin{tabular}{ccc}
\hline Pengetahuan & Frekuensi (n) & Persentase (\%) \\
\hline Baik & 10 & 9,2 \\
\hline Cukup & 63 & 57,8 \\
\hline Kurang & 36 & 33 \\
\hline Jumlah & 109 & 100 \\
\hline
\end{tabular}




\section{Journal of Community Engagement in Health}

Hasil kegiatan pengabdian masyarakat ini menunjukkan sebagian besar balita dengan status gizi baik yaitu 95 balita $(87,2 \%)$, berdasarkan data perkembangan balita sebagian besar memiliki perkembangan yang normal yaitu 97 balita (89\%). Pada pengetahuan ibu balita setelah dilakukan pendidikan kesehatan menunjukkan bahwa ibu balita sebagian besar memiliki pengetahuan yang cukup, sehingga program ini dapat dilanjutkan ke tahap selanjutnya untuk meningkatkan pemahaman ibu balita tentang stunting dan pencegahannya.

\section{PEMBAHASAN}

Dalam pelaksanaan kegiatan pengabdian masyarakat tersebut, kegiatan diikuti responden dari posyandu di desa Mojoranu kecamatan Sooko. Pendekatan yang dilakukan dengan pemberian pendidikan kesehatan tentang stunting, pemberian makanan sehat pada balita dan pemantauan pertumbuhan dan perkembangan balita. Pemberian informasi tentang pencegahan stunting bagi ibu balita sangatlah penting, dengan pemberian informasi kepada ibu balita diharapkan kejadian stunting dapat berkurang. Pendidikan tinggi memengaruhi kemampuan seseorang untuk berpikir atau menangkap, tetapi ini tergantung pada sumber informasi yang diperoleh ibu. Karena tidak selalu seorang ibu yang berpendidikan baik memiliki pengetahuan yang baik, karena pendidikan formal dalam hal ini meningkatkan kemampuan pikiran, sehingga jika ibu tidak terpapar informasi tentang perawatan anak yang baik menyebabkan kurang pengetahuan ibu yang berdampak pada pola ibu pada anak. memberi nutrisi.

Posyandu merupakan sumber pengetahuan terkait stunting, mengingat di Posyandu dilakukan penimbangan berat badan setiap bulan dan pengukuran tinggi badan pada bayi dan balita setiap sebulan sekali yang hasilnya dimasukkan pada grafik tinggi badan menurut umur pada buku KIA, sehingga dapat terdeteksi kejadian stunting. Penting keterlibatan bidan desa dan petugas gizi Puskesmas untuk pengisian grafik tinggi badan sesuai umur bayi dan balita sehingga kader posyandu dan ibu balita memahami pertumbuhan tinggi badan bayi dan balitanya. Pada kegiatan ini melibatkan kader posyandu dan kader di beri pengetahuan tentang stunting, faktor yang mempengaruhi, serta cara pencegahan stunting.

Hasil pelaksanaan kegiatan ini dapat meningkatkan pengetahuan ibu balita melalui media pendidikan dengan brosur. Brosur atau leaflet merupakan media informasi yang berinteraksi dengan komunikasi, dan antar individu dapat berinteraksi, dalam hal ini pengetahuan seseorang bukan hanya tergantung pada tingkat pendidikan saja tetapi harus ditunjang oleh faktor-faktor lain seperti pengalaman, keadaan sosial budaya lingkungan serta informasi dengan penyuluhan kesehatan. Yang mana dalam hal ini responden berjumlah 109. Responden telah memiliki tingkat pendidikan menengah atas (SMA) dilihat dari level pendidikan bukanlah suatu tingkat pendidikan yang rendah, sehingga ibu lebih cepat tanggap. Semakin baik tingkat pendidikan ibu, maka kemampuannya memahami informasi tentang gizi anak, peran ibu dalam memenuhi kualitas dan kuantitas gizi dapat ditingkatkan sehingga pertumbuhan dan perkembangan anak menjadi lebih optimal. Petugas kesehatan dapat memberikan penyuluhan atau pendidikan kesehatan kepada ibu. Dengan demikian, seorang ibu yang berpendidikan rendah tetap akan mendapatkan informasi perawatan yang baik atau mengasuh anak untuk meningkatkan status gizi aanak untuk mencegah stunting. Sebagian besar responden hanya sebagai ibu rumah tangga. memiliki waktu luang yang lebih banyak dengan ibu yang bekerja, sehingga ibu yang tidak bekerja memiliki lebih banyak waktu dirumah dan mengikuti pendidikan kesehatan ini. 


\section{KESIMPULAN}

Dalam Pengabdian masyarakat dilakukan Kegiatan pendidikan kesehatan tentang stunting, Demo Pemberian atau pengolahan makanan tambahan yang bergizi, dan juga melakukan pengukuran Pertumbuhan dan Perkembangan yang mana merupakan suatu sarana bagi dosen, mahasiswa, dan masyarakat untuk menjembatani ilmu stunting kepada masyarakat. Kegiatan ini memberikan sarana kepada mahasiswa untuk belajar memberikan pendidikan kesehatan dan juga pengkuran tumbuh kembang yang tepat langsung pada klien. Sedangkan pada kader kesehatan dan ibu balita mendapatkan pengetahuan langsung dan didampingi oleh calon tenaga kesehatan untuk meningkatkan pengetahuan tentang. Dan harapannya kedepan kegiatan pendidikan kesehatan ini dapat berlanjut dan menjadi program rutin memberdayakan calon tenaga kesehatan untuk terjun langsung membantu masalah di masyarakat.

\section{REFERENSI}

Anisa, N. dan Fauziah, W. (2020) Yang perlu Indonesia lakukan untuk mengurangi jumlah anak stunting. Available at: https://theconversation.com/yang-perlu-indonesialakukan-untuk-mengurangi-jumlah-anak-stunting-131148\%0A\%0A.

Behrman, J. R. et al. (2013) 'the Young Lives determinants and consequences of child growth project team (2013). Intergenerational transmission of poverty and inequality: Young Lives'. Oxford: University of Oxford (Young Lives technical note 117$)$.

Hall, C. et al. (2018) 'Maternal knowledge of stunting in rural Indonesia', International Journal of Child Health and Nutrition, 7(4), pp. 139-145.

West, J. et al. (2018) 'Stunting-Related Knowledge: Exploring Sources of and Factors Associated with Accessing Stunting-Related Knowledge among Mothers in Rural Indonesia', Health. Scientific Research Publishing, 10(09), p. 1250.

World Health Organization (2017) Stunted Growth and Development. Secondary Stunted Growth and Development 2017. Available at: http://www.who.int/nutrition/childhood_stunting_framework_leaflet_en.pdf?ua=1 $\% 0 \mathrm{~A}$. 